\title{
Large Scale Soil-Aquifer-Treatment (SAT-MAR) Physical Model Experiments to Improve Water Quality
}

\author{
Teresa E. Leitão (D)*, Tiago Martins (iD), Maria José Henriques, J. P. Lobo-Ferreira \\ Hydraulics and Environment Department, National Laboratory for Civil Engineering, Lisbon, Portugal
}

Received 05 February 2020; accepted 24 March 2020

\begin{abstract}
The effluents from agriculture practices usually contain several contaminants creating an environmental concern to downgradient water bodies. The use of SAT systems to improve the effluents water quality, during the transport of infiltrated water through the unsaturated and saturated zones, can bring a solution for water reclamation, water reuse, and overall as a water resources management tool. The research was carried out under MARSOL project were SAT experiments were executed in a physical (sandbox) model. These experiments aimed to contribute solving the problem of removing rice field contaminants from water, using a soil-aquifer prototype basin to treat water prior to its discharge in Melides lagoon, Portugal. The sandbox model was divided into three sections to test the adsorption and biodegradation capacity of three soil profiles, two of them including soil mixtures of sand with vegetal compost with different layouts. In each section, two tracer experiments were performed with spiked fertilizer and hydrocarbons. To analyse the tracer's behaviour, monitoring devices were installed in three piezometers for continuous in situ readings of $\mathrm{pH}, \mathrm{T}, \mathrm{EC}, \mathrm{ORP}$ and water level, besides water sampling hand-pump for chemical analysis. The results obtained in the experiments gave useful knowledge necessary to build an in situ facility.
\end{abstract}

Keywords: soil-aquifer treatment (SAT), physical model, water reuse, agriculture water reclamation.

\section{Introduction}

Managed Aquifer Recharge (MAR) solutions implementation and public acceptance - from actors, end-users and general public - could strongly benefit from experiments where the effectiveness of solutions is evidenced. Clogging issues and physic-chemical treatment of recharging water are two of the main issues requiring greater understanding. In MARSOL project (http://www.marsol.eu/), a physical sandbox model was built in LNEC's modelling facilities to conduct laboratory large scale infiltration and tracer tests, aiming to determine the soil infiltration rate and also the contaminants retention and/or degradation capacity. The facility was used to simulate Soil-Aquifer Treatment (SAT) in a MAR basin to remove rice paddy field pollutants prior to their discharge into Melides lagoon.

The SAT-MAR processes provide mechanical filtration of suspended particles and, resulting from intermittent aerobic and anaerobic conditions in the soil under the basin, nitrification and denitrification is facilitated, allowing the partial or total removal of organic and inorganic nitrogen, as well as organic carbon, phosphorus, non-aromatic organic, trace metals and pathogens (Miotliński et al., 2010). The nitrogen cycle in SAT can be quickly transformed into nitrates, very mobile in soils under normal conditions, but can be removed by denitrification under anaerobic conditions. Other components such as phosphorus are reduced by sorption and precipitation, and trace metals, with exception of boron, are attenuated and can be precipitated in the soil, especially under alkaline and aerobic conditions (National Research Council, 1994). The study of these aspects contributes to a greater understanding and operational reliability that can help increasing the effectiveness of SAT-MAR systems, and thus to secure water availability in areas of water stress.

\section{Materials and methods}

\subsection{Melides brief characterization}

Melides lagoon is a coastal ecosystem partially dependent from groundwater (Lobo Ferreira et al., 2013). The lagoon is a receptor of the total amount of pollutants load from surface origin collected by the drainage network of the Melides stream, and also of the pollutant load of groundwater flow that discharges into the surface water network or

${ }^{*}$ Corresponding author. E-mail: tleitao@lnec.pt 
directly to the lagoon. It receives annually a flow of about $20 \mathrm{hm}^{3}$, of which $14 \mathrm{hm}^{3}$ comes from runoff and about $6 \mathrm{hm}^{3}$ from the upper aquifer from the downstream zone of the basin (Oliveira \& Oliveira, 2012). The volume of this water body is $1.6 \mathrm{hm}^{3}$, being the water surplus drained to the ocean. Thus, the volume that the lagoon receives annually is about 12.5 times its average volume, bringing a significant renewal of lagoon water (Novo \& Oliveira, 2014).

The Melides sand that was used for this experiment has a high proportion of quartz $\left(\mathrm{SiO}_{2}\right)$ and alkaline feldspars [microcline - $(\mathrm{K}, \mathrm{Na}) \mathrm{AlSi}_{3} \mathrm{O}_{8}$ and albite - $\mathrm{NaAlSi}_{3} \mathrm{O}_{8}$ ] and a lower proportion of mica (illite $\left.\mathrm{KAl}_{2} \mathrm{Si}_{3} \mathrm{AlO}_{10} . \mathrm{OH}_{2}\right)$, chlorite $\left((\mathrm{Mg}, \mathrm{Fe})_{6}(\mathrm{Si}, \mathrm{Al})_{4} \mathrm{O}_{10}(\mathrm{OH})_{8}\right)$ and kaolinite $\left(\mathrm{Al}_{2} \mathrm{Si}_{2} \mathrm{O}_{5}(\mathrm{OH})_{4}\right)$. Its soil bulk density is $1.59 \mathrm{~g} / \mathrm{cm}^{3}$ and the porosity is 0.38 . The permeability was determined in a set of soil-column experiments with an average Darcy permeability ranging from 0.9 to $4.8 \mathrm{~m} / \mathrm{d}$ (Leitão et al., 2016).

\subsection{Physical (sandbox) model setup and monitoring devices}

The physical (sandbox) model was used to conduct laboratory large scale infiltration and tracer tests, both for saturated and non-saturated conditions. It allowed determining the soil (1) infiltration rate and (2) contaminants retention and/or degradation capacity. The facility is approx. $3.5 \mathrm{~m}$ long, $1 \mathrm{~m}$ wide and $2 \mathrm{~m}$ high (Figure 1) and can be filled with the porous medium (soil) to be studied, in this case the Melides sand.

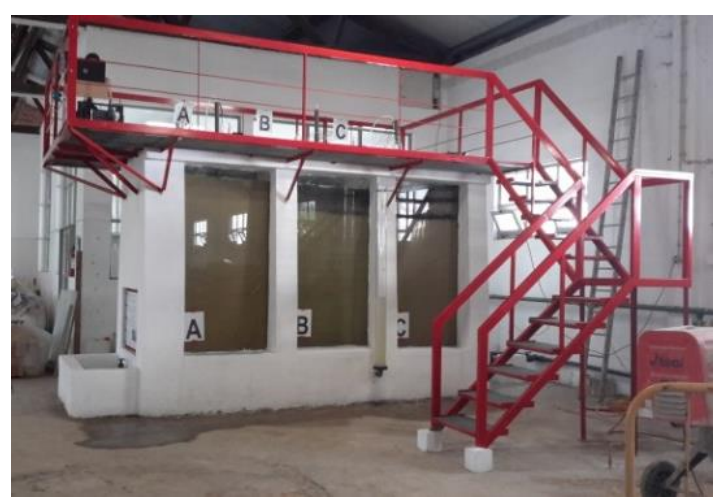

a)

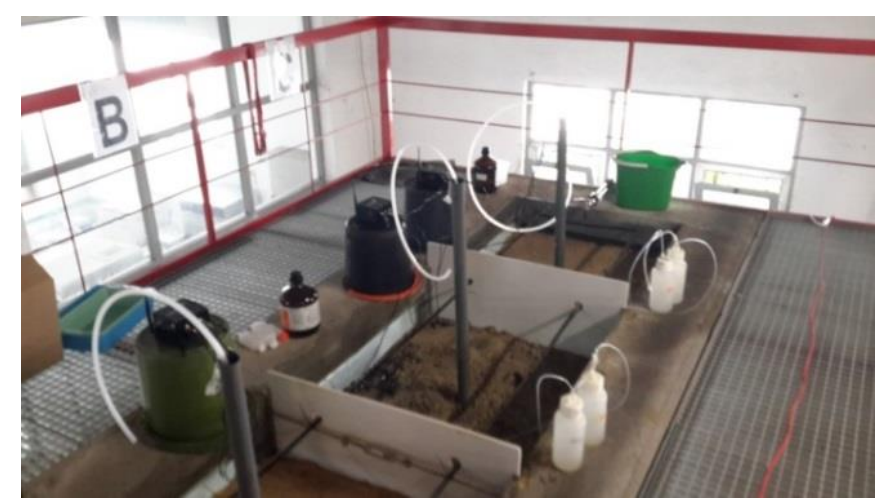

b)

Figure 1. LNEC physical (sandbox) model: a) Global view; b) Monitoring devices for the saturated and vadose zones

The sandbox model was divided into three sections (Figure 1 and Figure 2):

- Section A - Melides soil in all the vertical profile;

- Section B - $30 \mathrm{~cm}$ top layer of a mixture of Melides soil $(60 \%)$ and vegetal compost (40\% with $65 \%$ organic matter, i.e. the mixture has $26 \%$ of OM), followed by Melides soil in the remaining depth; and

- Section C - two layers of the same vegetal compost about $3 \mathrm{~cm}$ separated by $17 \mathrm{~cm}$ of Melides soil, followed by Melides soil in the remaining depth.

To analyse the tracers behaviour along their infiltration path into the soil profile, and to assess the soil behaviour of each section, the following monitoring devices were installed in each section: two Teflon capsules in the vadose zone, at two sampling depths, $30 \mathrm{~cm}$ and $60 \mathrm{~cm}$, and one piezometer with continuous in situ readings of $\mathrm{pH}$, T, EC, ORP of a Smart Water Kit (Ilie et al., 2017) and readings of T, EC and water level of CDT devices besides water sampling for chemical analysis (using a low-flow peristaltic pump). To sample the vadose zone water, the air inside the bottles needed to be sucked out with a vacuum pump. This process allowed sampling at the desired depths.

\subsection{Tracer experiments}

In each section (A, B and C) a tracer experiment with fertilizer spikes and hydrocarbons were performed with a pulse injection. The fertilizer corresponded to a common chemical fertilizer: $\mathrm{N}(12 \%), \mathrm{P}_{2} \mathrm{O}_{5}(12 \%), \mathrm{K}_{2} \mathrm{O}(17 \%), \mathrm{Cl}(0.9 \%)$, $\mathrm{MgO}(2 \%)$, as well as very small percentages of sulphur, boron and zinc. Furthermore, a NaCl conservative tracer was added to help on identifying the increase in electrical conductivity (EC) and, by means of this, the more adequate sampling periods.

The experiment was performed by spreading a volume of $0.5 \mathrm{~m}^{3}$ of water over the soil surface using 20 plastic containers with 25 litre capacity. The tracer volume was determined in order to correspond to approximately $20 \%$ of the soil basin total pore volume $\left(2.45 \mathrm{~m}^{3}\right.$, considering $38 \%$ soil average porosity).

The average flowrate $(\mathrm{Q})$ measured in the outflow before the experiment was $0.063 \mathrm{~L} / \mathrm{s}$, i.e. $5.44 \mathrm{~m}^{3} / \mathrm{d}$, corresponding to a velocity V (Q/Area) of $1.73 \mathrm{~m} / \mathrm{d}$ and a pore velocity $(\mathrm{V} / \mathrm{n})$ of $4.55 \mathrm{~m} / \mathrm{d}$. Although this value was not obtained for full saturation conditions, it is equivalent to the values previously measured in laboratory soil-columns for saturated conditions. Considering the $2.45 \mathrm{~m}^{3}$ sandbox pore volume (PV), it takes about 10.8 hours for a complete PV to flow throughout the sandbox (or each 24 hours about 2.22 PV is percolated in the sandbox). 


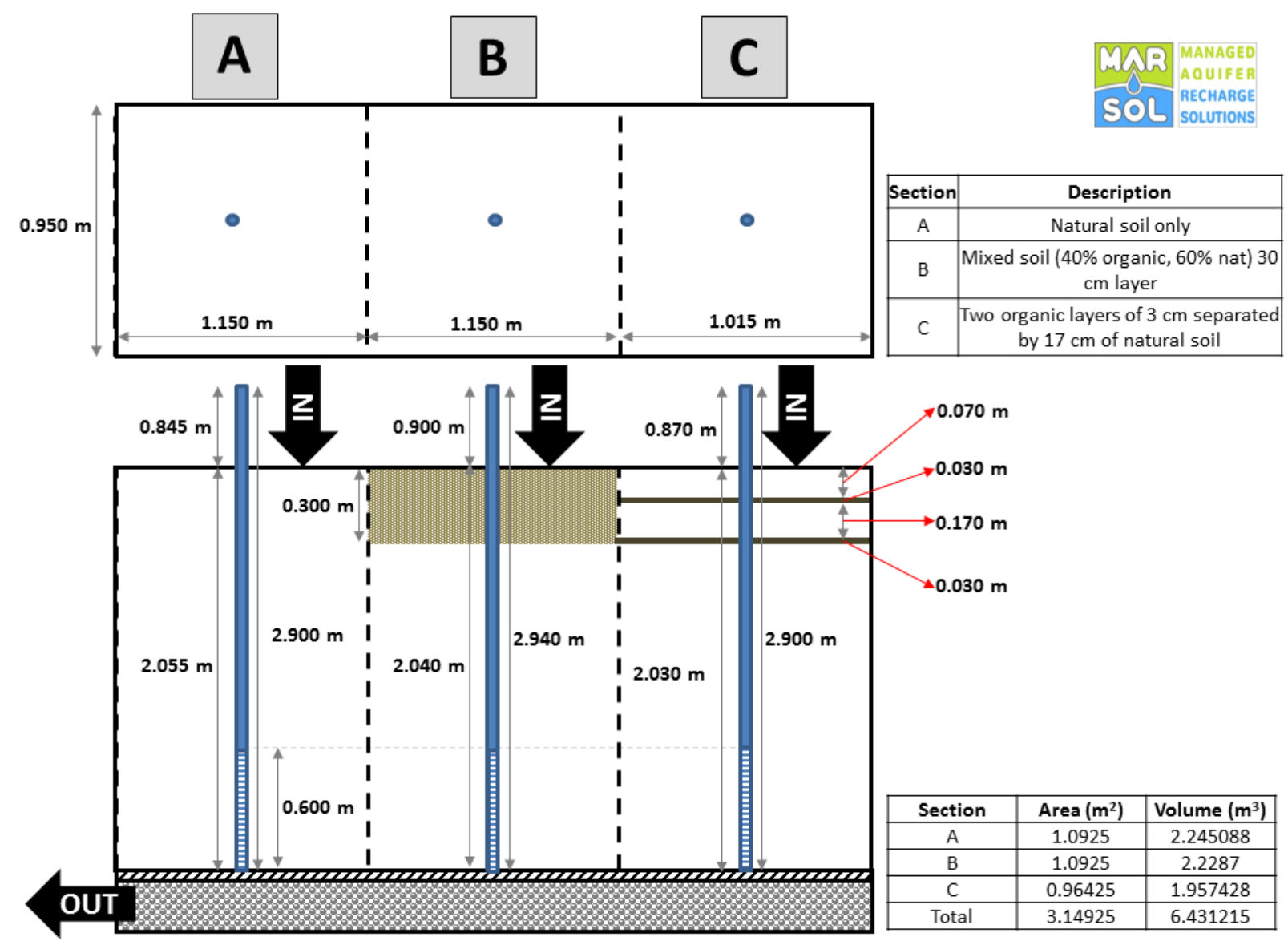

Figure 2. Schematic diagram of the sandbox model dimensions and soil mixtures used in MARSOL SAT experiments

The tracer concentration in the tracer spike water was calculated in order to correspond to the typical dose advised for most horticultural species, i.e. $500 \mathrm{~kg} / \mathrm{ha}$. For the hydrocarbons, the tracer (diesel) concentration was defined to be a value about ten times higher than the chemical analysis detection limit of $10 \mu \mathrm{g} / \mathrm{L}$. NaCl concentration was picked out in order to produce an increase in water electrical conductivity. Table 1 presents the analytical results of the injected tracer.

Table 1. Tracer concentration analytical results

\begin{tabular}{|c|c|c|c|c|c|c|c|c|c|c|c|}
\hline Element & $\mathrm{NO}_{3}^{-}$ & $\mathrm{NO}_{2}^{-}$ & $\mathrm{NH}_{4}^{+}$ & $\mathrm{Ca}^{2+}$ & $\mathrm{Mg}^{2+}$ & $\mathrm{Na}^{+}$ & $\mathrm{K}^{+}$ & $\mathrm{SO}_{4}^{2-}$ & $\mathrm{Cl}^{-}$ & $\mathrm{HCO}_{3}^{-}$ & $\mathrm{TH}^{-1}$ \\
\hline Unit & \multicolumn{10}{|c|}{$\mathrm{mg} / \mathrm{L}$} & $\mu \mathrm{g} / \mathrm{L}$ \\
\hline Concentration & 5,9 & $-0,01$ & 3,7 & 18 & 3,1 & 180 & 6,9 & 27 & 275 & 53,8 & 78 \\
\hline
\end{tabular}

\section{Results and conclusions}

The experiment was carried out for 24 hours, and the tracer injection period lasted 30 minutes. The water percolated during the whole experiment corresponded to approximately 3.8 times the pore volume of the sandbox model. This value corresponded to more saturated conditions than before the experiment.

Figure 3 presents the results concerning the water level and the electrical conductivity (EC). The figure shows a fast increase of the water level after the tracer injection started. After the tracer injection stopped there was a period with now inflow until the tracer was gone. The water inflow during the remaining period of the experiment was tried to be kept constant, but some small oscillations in the water pressure have occurred. Nevertheless, the main reason for the water table decrease was due to the release of water in the outflow tap, which was done in order to balance the inflow with the outflow, while stabilizing the water table.

Concerning the electrical conductivity, Figure 3 shows the three peak (breakthrough curve maximum value) arrivals. It is possible to observe that the tracer arrived first to PzA and with higher EC values when compared to the tracer arrival in Section B and C, as a result of the higher retention capacity of Melides soil mixed with vegetal compost. 


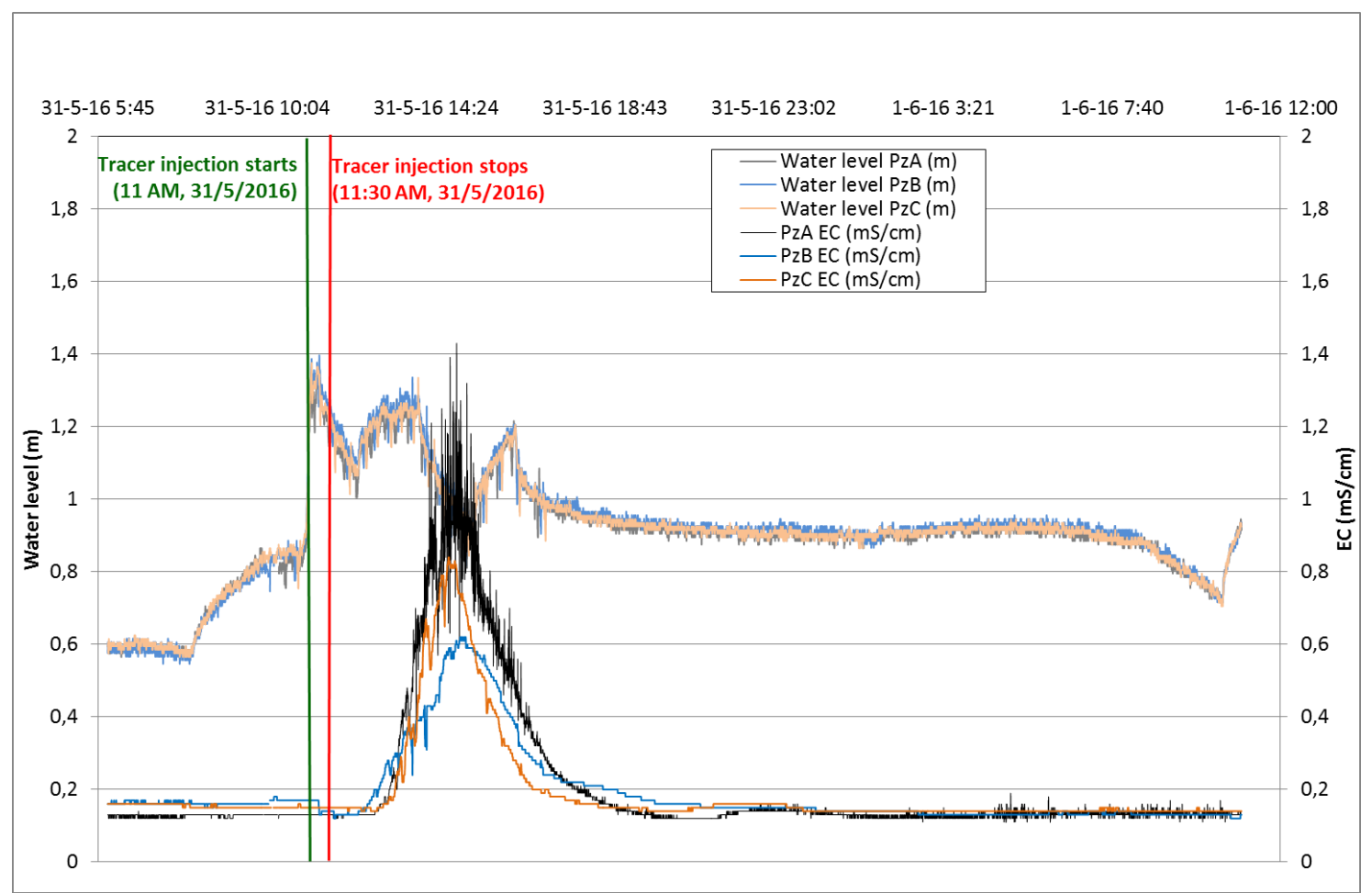

Figure 3. Piezometric water level and electrical conductivity values in the three piezometers

In addition to the continuous measurement with the CTD diver, several discrete samples were retrieved from the six vadose zone cups and the three piezometers during the whole experiment period. tion A.

Figure 4 presents the breakthrough curves obtained in the saturated water from the piezometer installed in Sec-

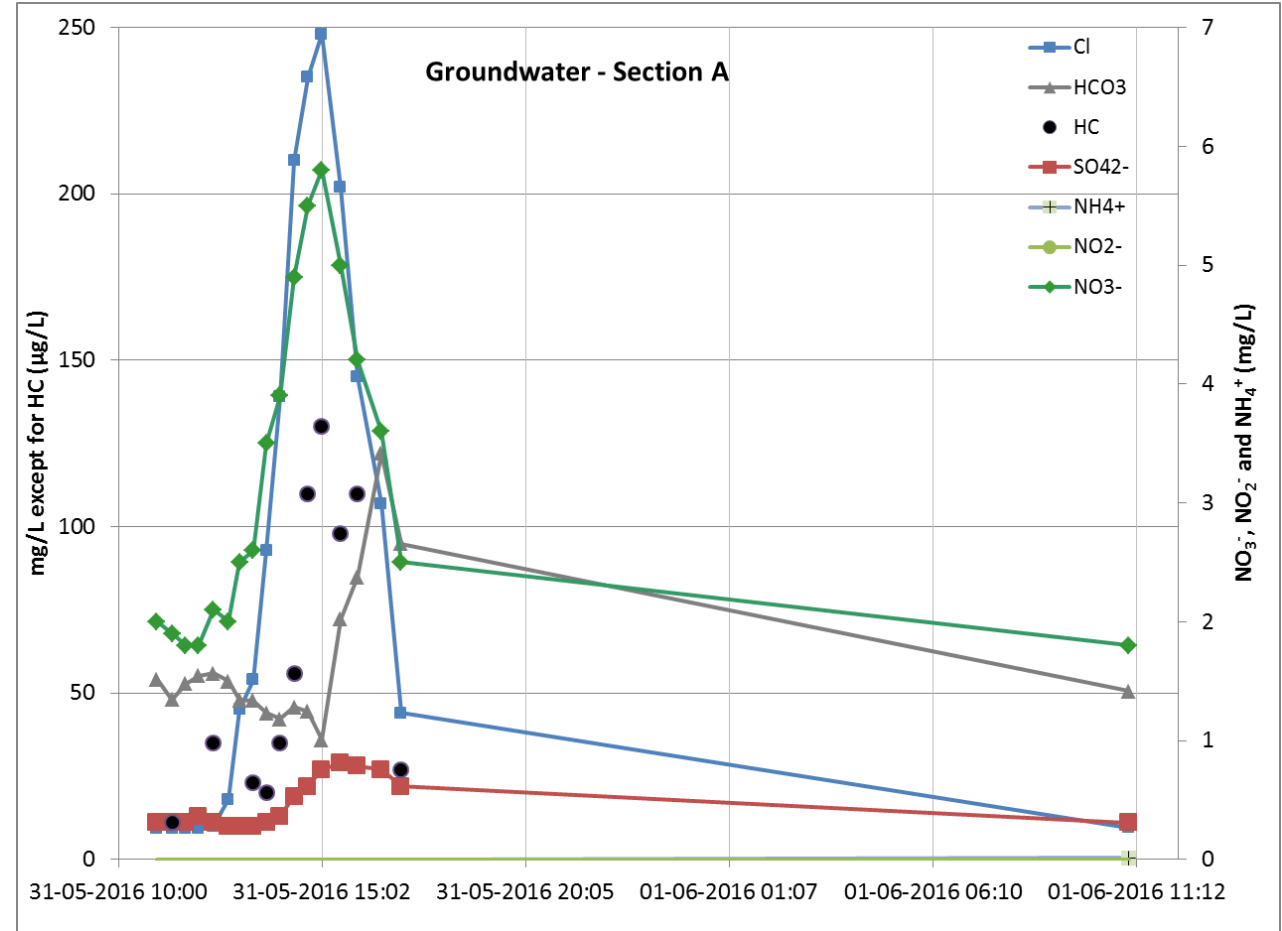

Figure 4. Breakthrough curves obtained for the water samples from the Section A piezometer 
The sharp and symmetrical curves obtained both for chloride $\left(\mathrm{Cl}^{-}\right)$and nitrate $\left(\mathrm{NO}_{3}{ }^{-}\right)$, together with the simultaneous peak arrival of both ions in concentrations similar to the initial concentration of the tracer (cf. Table 1), confirms the inert character of Melides sand. Neither nitrite $\left(\mathrm{NO}_{2}{ }^{-}\right)$nor ammonia $\left(\mathrm{NH}_{4}{ }^{+}\right)$were found in the piezometer water samples during the experiment. Possibly the $\mathrm{NH}_{4}{ }^{+}$existing in the tracer $(3.7 \mathrm{mg} / \mathrm{L})$ was nitrified with the presence of oxygen (as can be seen by the small initial peak in $\mathrm{NO}_{3}^{-}$):

$$
\begin{gathered}
2 \mathrm{NH}_{4}^{+}+3 \mathrm{O}_{2} \rightarrow 2 \mathrm{NO}_{2}^{-}+2 \mathrm{H}_{2} \mathrm{O}+4 \mathrm{H}^{+} ; \\
2 \mathrm{NO}_{2}^{-}+\mathrm{O}_{2} \rightarrow 2 \mathrm{NO}_{3}^{-} .
\end{gathered}
$$

In fact, the samples which were collected in the vadose zone (Figure 5) showed the presence of $\mathrm{NH}_{4}{ }^{+}$in the water at a depth of 30 to $60 \mathrm{~cm}$ after 24 hours (the first samples did not have enough water for this analysis), in minor concentrations when compared to the input of $3.7 \mathrm{mg} / \mathrm{L}$. For the soil samples collected at two depths after the experiment, only nitrite and $\mathrm{HC}$ were found (Table 2).

The concentration in hydrocarbons (HC) along the experiment showed values higher than the average tracer concentration, possibly due to the difficulty of making a good mixture of HC in the injected water or eventually soil contamination during the collecting procedure. So, possibly the portion of the tracer injected in Section A had higher values than the mixture analysed. Nonetheless, the $\mathrm{HC}$ were retained in very small concentrations $(10 \mathrm{mg} / \mathrm{kg}) \mathrm{in}$ Melides soil (Table 2). Two peaks can be seen throughout the experiment.

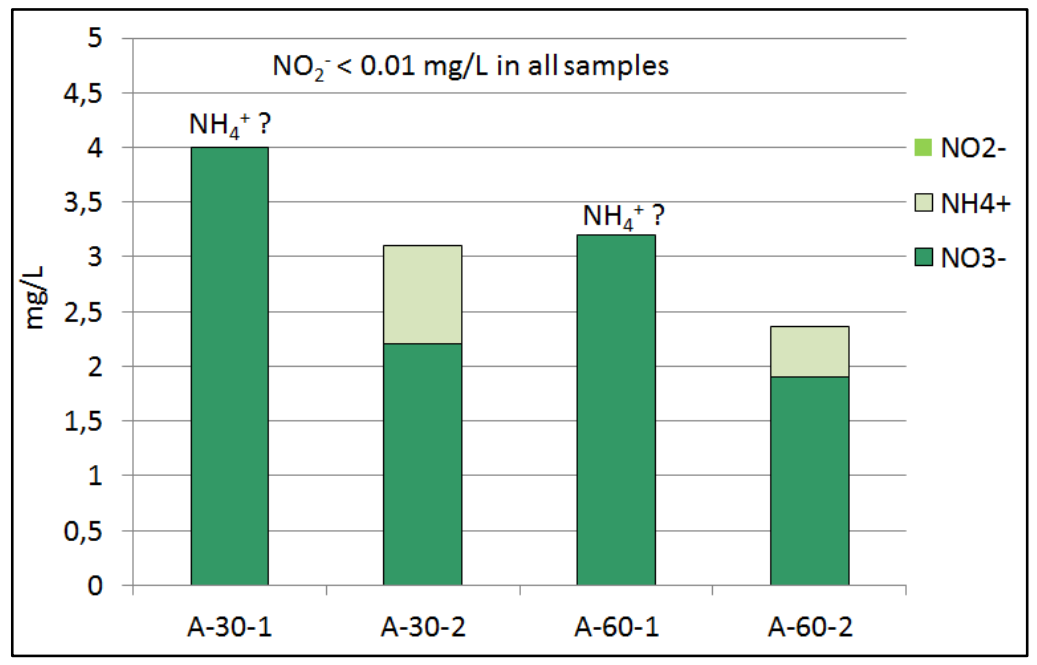

Figure 5. Nitrogen concentrations in the vadose zone capsules $(30 \mathrm{~cm}$ and $60 \mathrm{~cm})$ from Section A

\begin{tabular}{|c|c|c|c|c|c|c|}
\hline \multirow{2}{*}{ Designation } & \multicolumn{6}{|c|}{ Soil (mg/kg DW) } \\
\hline & $\mathrm{NO}_{3}^{-}$ & $\mathrm{NO}_{2}^{-}$ & $\mathrm{NH}_{4}^{+}$ & $\mathrm{PO}_{4}{ }^{3+}$ & $\mathrm{SO}_{4}{ }^{2-}$ & $\mathrm{HC}$ \\
\hline A_30_Soil & $<20$ & 0.080 & $<0.5$ & $<0.05$ & $<0.1$ & 10 \\
\hline A_60_Soil & $<20$ & 0.090 & $<0.5$ & $<0.05$ & $<0.1$ & $<10$ \\
\hline B_30_Soil & $<20$ & 0.135 & $<0.5$ & $<0.05$ & $<0.1$ & $<10$ \\
\hline B_60_Soil & $<20$ & 0.134 & $<0.5$ & $<0.05$ & $<0.1$ & 36 \\
\hline C_30_Soil & $<20$ & 0.132 & $<0.5$ & $<0.05$ & $<0.1$ & 70 \\
\hline C_60_Soil & $<20$ & 0.077 & $<0.5$ & $<0.05$ & $<0.1$ & $<10$ \\
\hline
\end{tabular}

Table 2. Results from the chemical analysis of soil samples collected after the experiment finished

In the last sample, taken $24 \mathrm{~h}$ after the tracer injection, the concentrations of all chemical parameters were similar to the values before the experiment.

Figure 6 presents the breakthrough curves obtained in the saturated water from the piezometer installed in Section $B$, in which the first $60 \mathrm{~cm}$ of soil was a mixture of Melides soil $(60 \%)$ and vegetal compost (40\% with $65 \%$ organic matter), followed by Melides soil in the remaining depth.

The breakthrough curve for nitrates showed a higher dispersion when compared to $\mathrm{Cl}$ and to the results from Section A. Besides, the peak of nitrate arrival was 30 minutes slower (at 15:32) and has increased when compared to the initial tracer (from $5.9 \mathrm{mg} / \mathrm{L}$ to almost $7 \mathrm{mg} / \mathrm{L}$ ). The presence of nitrite $\left(\mathrm{NO}_{2}{ }^{-}\right.$) (see also Figure 7 ), confirms the transformation of $\mathrm{NH}_{4}{ }^{+}$into nitrite and nitrate through a nitrification process. Besides, it is possible that some of the 
nitrate was subject to denitrification in the presence of organic matter $\left(\mathrm{CH}_{2} \mathrm{O}\right)$, producing bicarbonate $\left(\mathrm{HCO}_{3}{ }^{-}\right)$in the process:

$$
5 \mathrm{CH}_{2} \mathrm{O}+4 \mathrm{NO}_{3}{ }^{-} \rightarrow 2 \mathrm{~N}_{2}(\mathrm{~g})+4 \mathrm{HCO}_{3}^{-}+\mathrm{CO}_{2}+3 \mathrm{H}_{2} \mathrm{O}
$$

The existence of a decrease in $\mathrm{HCO}_{3}{ }^{-}$concentrations, followed by a peak that is delayed compared to nitrate or $\mathrm{NaCl}$, is a common phenomenon in all three experiments. The peak should probably be a result of Eq. (3), and the decrease might be due to some sorption phenomena.

Concerning the HC, the soil from Section B showed a better ability to retain these contaminants than Melides soil alone. The $\mathrm{HC}$ were retained roughly at a depth of $60 \mathrm{~cm}$ (Table 2).

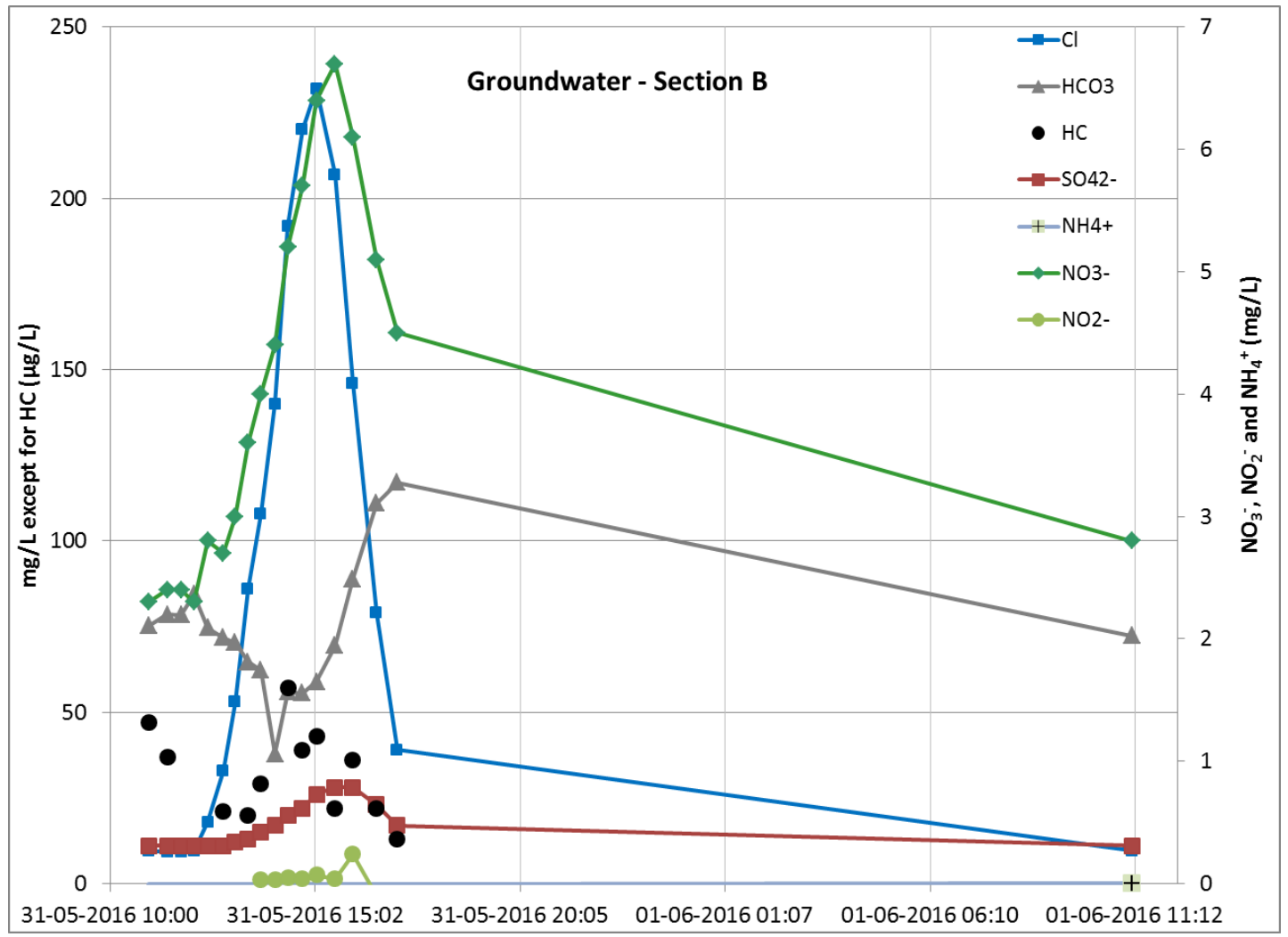

Figure 6. Breakthrough curves obtained for the water samples from the Section B piezometer

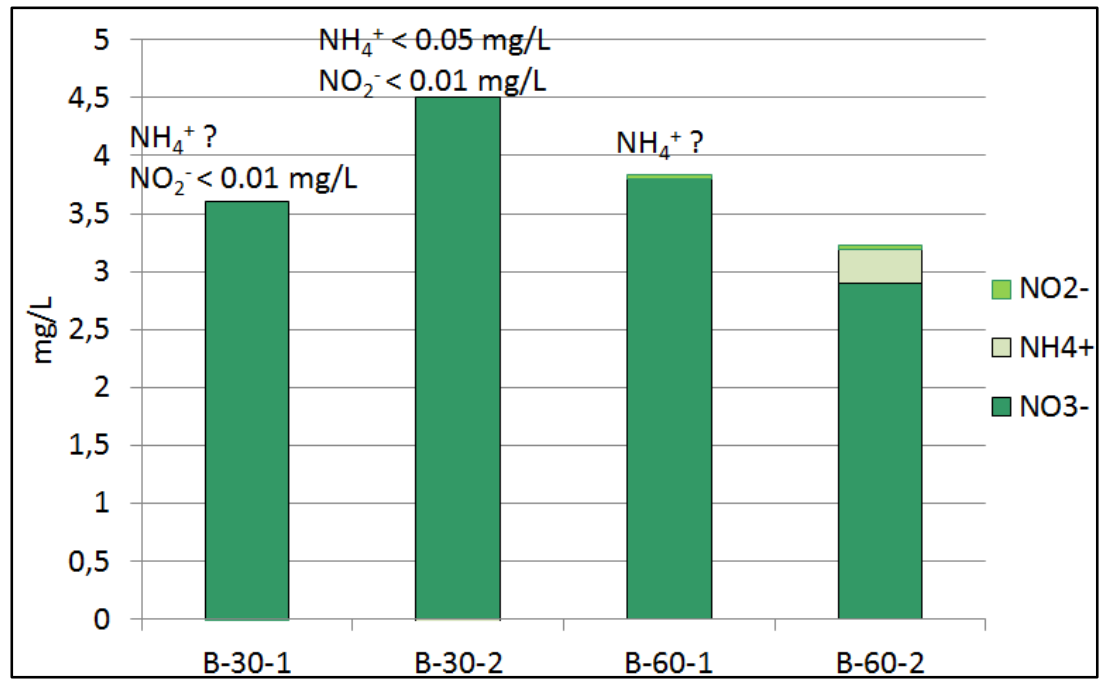

Figure 7. Nitrogen concentrations in the vadose zone capsules $(30 \mathrm{~cm}$ and $60 \mathrm{~cm}$ ) from Section $\mathrm{B}$ 
In the last sample, $24 \mathrm{~h}$ after the tracer injection, the concentrations of all chemical parameters were similar to the initial values.

Figure 8 presents the breakthrough curves obtained in the saturated water from the piezometer installed in Section $C$, with two vegetal compost layers of about $3 \mathrm{~cm}$ separated by $17 \mathrm{~cm}$ of Melides soil, followed by Melides soil in the remaining depth.

The breakthrough curve for nitrates showed lower maximum values when compared to Section B but also the formation of nitrite $\left(\mathrm{NO}_{2}^{-}\right)$through a nitrification process. Denitrification is possible (Figure 9) but the escape of $\mathrm{N}_{2}$ to the atmosphere should be minor due to the lower permeability of the more organic layer. The retention of HC showed the best results when comparing to the three sections. The concentration retained in the first soil layers was higher Table 2 and therefore the concentration on the water was the lowest (Table 2).

In the last sample, $24 \mathrm{~h}$ after the tracer injection, the concentrations of all chemical parameters were similar to the initial values.

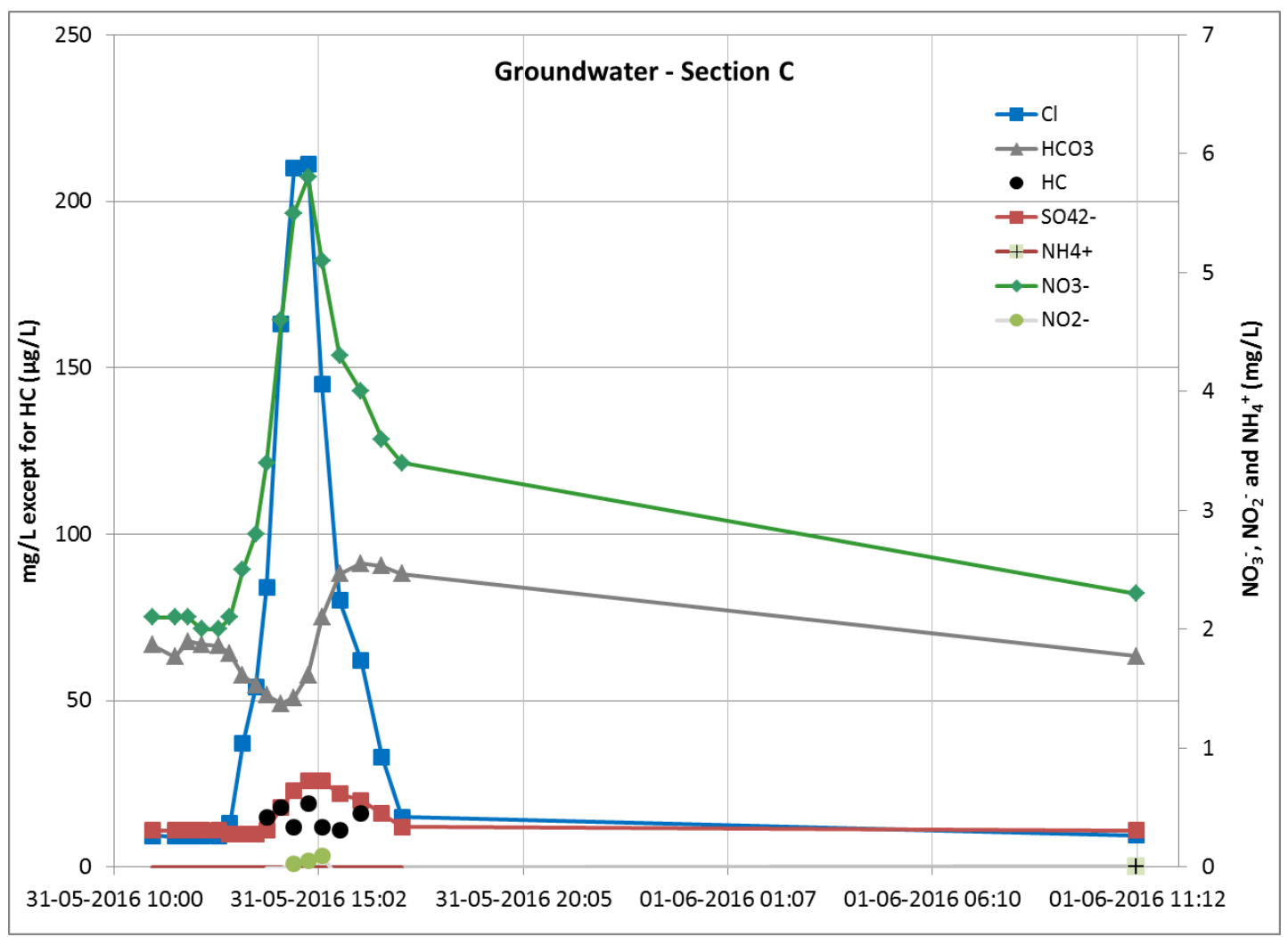

Figure 8. Breakthrough curves obtained for the water samples from the Section C piezometer

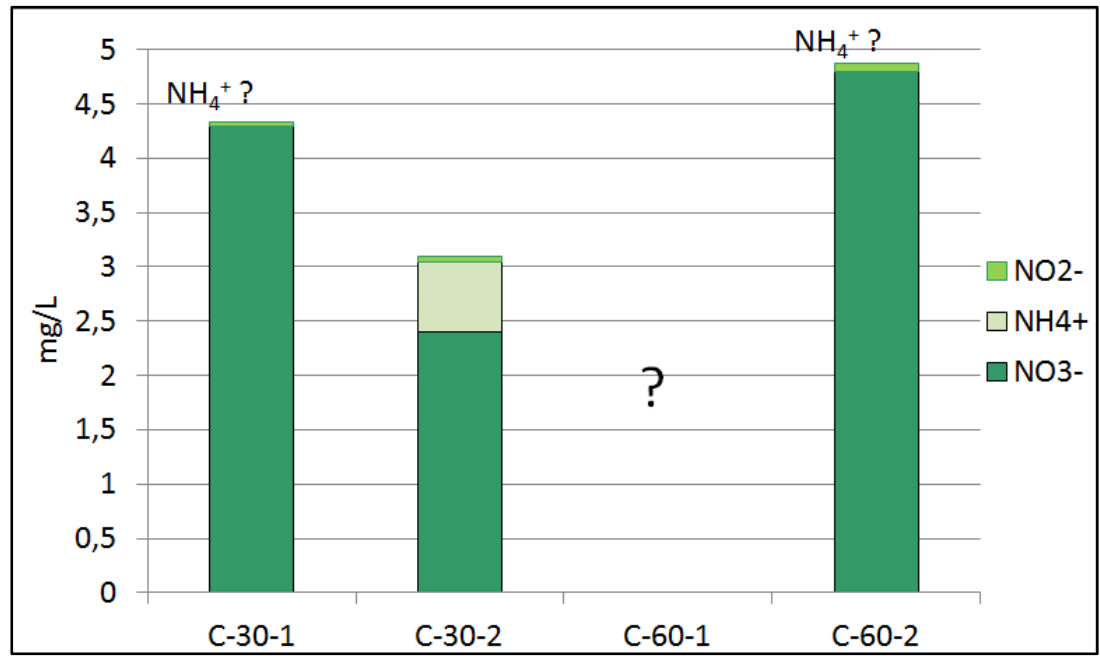

Figure 9. Nitrogen concentrations in the vadose zone capsules $(30 \mathrm{~cm}$ and $60 \mathrm{~cm})$ from Section $\mathrm{C}$ 


\section{Discussion}

The main purpose of the physical (sandbox) model experiments was to assess the ability of a SAT-MAR scheme to retain the contaminants ( $\mathrm{N}$ and hydrocarbons) existing in the water from the rice paddy fields. Although the ability to denitrify (nitrate to $\mathrm{N}_{2}$ ) is modest and more effective only in the first soil layer, the removal of total hydrocarbons seems effective, particularly in Sections where organic soil layers were used. These layers were clearly more effective in the removal of $\mathrm{HC}$ in Section C. Nitrification (from ammonia to nitrate) and denitrification (from nitrate to gaseous $\mathrm{N}$ ) were likely to have occurred in the first soil layers due to the presence of oxygen and the possibility of $\mathrm{N}_{2}$ gas to escape to the atmosphere. The presence of an organic layer (Section B and C) favours denitrification and seems to be more effective in Section C (although this is not so clear in Experiment 2 due to the previous soil disturbance due to sampling).

\section{Funding}

The research leading to these results has received funding from the European Union Seventh Framework Programme (FP7/2007-2013) under Grant Agreement no. 619120 for the research project MARSOL.

\section{Author contributions}

Teresa E. Leitão, Tiago Martins and J. P. Lobo-Ferreira conceived and designed the experiments; Teresa E. Leitão, Tiago Martins and Maria José Henriques performed the experiments and analysed the data; Teresa E. Leitão and Tiago Martins wrote the paper, and the other authors glanced through the manuscript.

\section{Disclosure statement}

The authors declare no conflict of interest. The founding sponsors had no role in the design of the study; in the collection, analyses, or interpretation of data; in the writing of the manuscript, and in the decision to publish the results.

\section{References}

Ilie, A. M. C., Vaccaro, C., Rogeiro, J., Leitao, T. E., \& Martins, T. (2017). Configuration, programming and implementation of 3 Smart Water network wireless sensor nodes for assessing the water quality. IEEE Digital Xplore Proceedings. https://doi.org/10.1109/UIC-ATC.2017.8397442

Leitão, T. E., Martins, T., Henrinques, M. J., Lobo Ferreira, J. P., Rogeiro, J., \& Ilie, A. M. C. (2016). MARSOL - Demonstrating managed aquifer recharge as a solution to water scarcity and drought. Physical (Sandbox) Modelling of Selected MARSOL Demo Sites. http://www.marsol.eu/files/marsol_d12-5_physical-model_20161011.pdf

Lobo Ferreira, J. P., Novo, M. E., \& Oliveira, L. (2013). Análise da Contribuição das Fontes Poluentes para a Carga Total de Nitratos e Fosfatos que Afluem à Lagoa de Melides por Transporte Subterrâneo. $11^{\circ}$ SILUSBA "A Cooperação para a Água". Maputo, Moçambique.

Miotliński, K., Barry, K., \& Dillon, P. (2009). Alice Springs SAT project hydrological and water quality monitoring report 20082009. CSIRO: Water for a Healthy Country National Research Flagship. 85 p.

National Research Council. (1994). Ground water recharge using waters of impaired quality. National Academy Press. Washington D.C. 282 p.

Novo, M. E., \& Oliveira, L. G. S. (2014). Uso de cenários de alterações climáticas para previsão do estado de Aquíferos e EDAS. Caso de Estudo: Melides. Revista Recursos Hídricos, 35(2), 77-87. https://doi.org/10.5894/rh35n2-7

Oliveira, M. M., \& Oliveira, L. S. (2012). Water, aquatic ecosystems and human activity project PROWATERMAN (5 ${ }^{\text {th }}$ Thematic Report). Recharge and direct runoff assessment of Querença-Silves aquifer system catchment area (Report 180/2012-NAS). LNEC, pp. 108. [Água, Ecossistemas Aquáticos e Atividade Humana. Projeto PROWATERMAN. Quinto Relatório Temático - Estimativa da recarga e do escoamento direto na área de drenagem do sistema aquífero Querença-Silves] (in Portuguese). 